\title{
Estetyczne aspekty tworzenia i odbioru sztuki przez osoby z wadami słuchu
}

\begin{abstract}
Woźniak-Czech Ewelina, Estetyczne aspekty tworzenia i odbioru sztuki przez osoby $z$ wadami słuchu [The aesthetic aspects of creation and reception of art by people with hearing impairments]. „Przestrzenie Teorii” 13. Poznań 2019, Adam Mickiewicz University Press, pp. 271-291. ISSN 1644-6763. DOI 10.14746/pt.2019.31.15.
\end{abstract}

The aim of the article is to analyse the aesthetic aspects of the reception and creation of art by people with hearing impairments. For most people, hearing loss is unimaginable and is often understood only in the context of communication problems. Meanwhile, deaf people perceive their otherness completely differently. Deafness is a total experience, affecting not only the physical aspect, but also changing the perception of reality as a whole. Divergences in the way of perceiving the world, resulting from the exclusion of one of the basic senses, are particularly visible in the field of art, especially in those areas that use sound effects. The large variety of types of deafness does not allow for broad generalizations or building some kind of universal theory of reception. Therefore, from the perspective of deaf people, contact with art is very individual and intimate, which also affects the issue of their artistic creation. The author of the article touches upon the problem of the visuality of sign language and its artistic possibilities. She analyses the perception preferences of people with hearing impairments, exposing the issue of polysensory perception, and presents the most interesting artistic projects created both by the deaf and those that allow to build multidirectional relations between the parallel worlds of the deaf and hearing people.

KEYWORDS: aesthetics, deafness, reception of work of art, sign language , polysensory perception

Każdy rodzaj percepcji jest potencjalnie estetyczny

A. Berleant

Grupa osób z dysfunkcjami słuchu jest bardzo zróżnicowana. Anna Żórawska, analizując możliwości przystosowania ścieżek muzealnych dla odbiorców z niepełnosprawnością słuchowa, zwraca uwagę choćby na niejednorodne nazewnictwo poszczególnych rodzajów niedosłuchu:

Mówi się o osobach z wadami słuchu, głuchych, niesłyszących, niedosłyszących, słabosłyszących, głuchoniemych, wreszcie o Głuchych (pisanych wielką litera). [...] Osoby z niepełnosprawnością słuchu klasyfikuje się w zależności od poziomu niesłyszenia, ale też [...] zdolności komunikowania się z osobami niemającymi kłopotów ze słuchem. Umiejętność ta jest najczęściej wynikiem wychowania lub przebytej 
ścieżki edukacyjnej, które przekładają się na poziom znajomości języka polskiego oraz możliwość korzystania z niego ${ }^{1}$.

Rozróżnienie to ma znaczenie nie tylko ze względu na potrzebne usprawnienia techniczne. Przede wszystkim jest kluczowe dla analizy preferencji odbiorczych i sposobu postrzegania sztuki przez osoby z wadami słuchu, a zarazem nie pozwala na szerokie uogólnienia czy budowanie jakiejś uniwersalnej teorii odbioru.

Ewa Pakalska, autorka bloga I'm not there, teatrolożka, osoba z wrodzoną wadą słuchu w stopniu głębokim, nosząca aparaty, wyraźnie zarysowuje trudności, z jakimi musi się zmierzyć słyszący badacz, jeśli chce choć w niewielkim stopniu wejść do świata ciszy:

Jak to jest [niedostyszeć]? Ja akurat kilkakrotnie to słyszałam i chociaż osoby o to pytajace zwyczajnie były ciekawe i chciały dowiedzieć się czegoś więcej o głuchocie, to jednak w pewnym momencie się wkurzyłam i wypaliłam: A jak to jest słyszeć? Wiem, że przecież dla zdecydowanej większości ludzi sprawny słuch jest czymś oczywistym, naturalnym i po prostu nie są w stanie wyobrazić świata bez większości dźwięków, bez możliwości usłyszenia ludzkiego głosu czy muzyki. Ale chodziło mi tutaj o to, że bardzo trudno jest opisać stan słyszenia/niesłyszenia osobie „z drugiej strony", bo to sa sytuacje totalne, obejmujace nie tylko sam aspekt fizyczny, ale także percepcję całej rzeczywistości ${ }^{2}$.

Postawę wobec sztuki reprezentowana przez osoby niesłyszące, tak samo jak w każdym innym przypadku, warunkują różne czynniki edukacyjne, środowiskowe czy rodzinne, jednakże naturalny dla nich sposób

${ }^{1}$ A. Żórawska, Gość z niepetnosprawnościa stuchu w muzeum, [w:] ABC Gość niepetnosprawny w muzeum. „Szkolenia Narodowego Instytutu Muzealnictwa i Ochrony Zbiorów” 2013, nr 2, s. 54, <https://www.nimoz.pl/files/publications/17/ABC_Gosc_niepelnosprawny_lekki.pdf> [dostęp: 10.11.2018]. Oliver Sacks zauważa, że: „Samo określenie «niesłyszący» lub "głuchy» jest dość nieprecyzyjne. Jest ono na tyle ogólne, że możemy przez nie rozumieć różne stopnie upośledzenia słuchu zarówno w sensie jakościowym, jak i w znaczeniu, które można by określić jako «egzystencjalne»" (zob. O. Sacks, Zobaczyć głos. Podróż do świata ciszy, przeł. A. Małaczyński, Poznań 1998, s. 20-21). W dalszej części rozważań będę używać tych pojęć zamiennie, w rozumieniu pewnego ogółu ludzi z wadami narządu słuchu. Termin „Głusi” (zapisany wielką litera) będzie natomiast stosowany wyłącznie w odniesieniach do Kultury Głuchych.

${ }^{2}$ E. Pakalska, Niedoskonaty odbiornik, <https://pakalska.blogspot.com/2015/03/niedoskonay-odbiornik.html> [dostęp: 27.06.2019]. Sposób percypowania świata przez osoby niesłyszące od urodzenia (zwłaszcza używające języka migowego) jest dla słyszących w znacznej mierze niedostępny. Wynika to nie tylko z faktu wyłączenia lub ograniczenia działania jednego ze zmysłów, ale także z różnic w rozwoju neurologicznym. Sacks stwierdza, że „u głuchoniemych posługujących się językiem migowym lewa półkula w pewnym sensie «przejmuje» percepcję wizualno-przestrzenna, modyfikuje ją i wyostrza w specyficzny, nie mający precedensu sposób, nadając jej wysoce analityczny i abstrakcyjny charakter i umożliwiajacc w ten sposób funkcjonowanie zarówno języka wizualnego, jak i wizualnego myślenia”. Zob. O. Sacks, dz. cyt., s. 136. 
percypowania jest całkowicie odmienny niż ten znany ludziom słyszącym. Oczywistą różnicę i zarazem przeszkodę stanowi sposób komunikacji. Świat niesłyszących jest dla „zdrowych” ${ }^{3}$ obcy w znacznie większym stopniu niż na przykład zagraniczne kultury posługujące się językiem mówionym. Dla osób porozumiewających się w Polskim Języku Migowym ${ }^{4}$ język polski jest całkowicie nieznany i nierzadko niemożliwy do opanowania z różnych względów ${ }^{5}$. PJM niewiele ma wspólnego z fonetycznym językiem polskim nie jest po prostu przekładaniem słów na gesty. Funkcjonuje na zupełnie innej płaszczyźnie, ma własną gestykulacyjna gramatykę i właściwie jest nieprzekładalny bezpośrednio na słowa ${ }^{6}$. Różnice są tak duże, że PJM stał się podstawą do wyodrębnienia się polskiej Kultury Głuchych - społeczności, która postrzega siebie samą jako mniejszość kulturowa. Co więcej, każdy jego użytkownik miga w charakterystyczny dla siebie sposób, co sprawia dodatkową trudność dla zewnętrznych obserwatorów, zupełnie jak nietypowy akcent, wady wymowy czy inne utrudnienia w językach mówionych.

Wydaje się, że bariera komunikacyjna powinna zniknać lub przynajmniej znacząco zmaleć w przypadku niesłyszących, którzy używają aparatów słuchowych i posługuja się mowa ${ }^{7}$. Tymczasem - paradoksalnie - znajdują się oni w najgorszej sytuacji. Takie osoby zwykle funkcjonują wśród ludzi słyszących, zatem często nie znają języka migowego lub posługują się Systemem Językowo-Migowym ${ }^{8}$, który jest tworem sztucznym i niewiele ma wspólnego z PJM. Nie znaczy to jednak, że w pełni identyfikują się ze „zdrowym” światem. Dzięki technicznemu wzmocnieniu słuchu interpretacja dźwięku staje się możliwa, jednak to wciąż nie są te same dźwięki, które

${ }^{3}$ Głuchota jest uznawana za rodzaj niepełnosprawności, ale tak naprawdę nie ogranicza w żaden sposób umiejętności poznawczych czy ruchowych. Dlatego określenia „zdrowi” używam umownie i zapisuję w cudzysłowie.

${ }^{4}$ Dalej jako PJM.

${ }^{5}$ Żórawska podkreśla, że: „nauka polskiego języka zajmuje dużo czasu dzieciom niesłyszącym i sprawia im ogromną trudność. Dzieci, dla których to język migowy jest językiem naturalnym, nie rozumieja, dlaczego zmusza się je do nauki języka, który dla nich zawsze będzie tym drugim. Niemniej jednak te dzieci, których najbliżsi położyli ogromny nacisk na naukę języka polskiego, posługują się nim najlepiej i często, lepiej lub gorzej, potrafią czytać z ruchu warg. Sa jednak i osoby, którym język polski sprawia większą trudność”. A. Żórawska, dz. cyt., s. 56.

${ }^{6}$ Historię badań nad językiem migowym, jego gramatyką i znaczeniem szczegółowo opisuje Sacks na przykładzie angielskiego języka migowego (ASM). Zob. O. Sacks, dz. cyt., s. 111-129.

${ }^{7}$ Do tej grupy zaliczam zarówno osoby niesłyszące od urodzenia, implantowane, jak i osoby noszące aparat słuchowy ze względu na wadę nabytą. Istotny jest dla mnie znaczny stopień niedosłuchu wykluczający funkcjonowanie bez aparatu słuchowego.

${ }^{8}$ System Językowo-Migowy (zwany też językiem miganym) oparty jest na gramatyce języka polskiego i został stworzony przez ludzi słyszących. Towarzyszy mu wypowiadanie tekstu, który jest tłumaczony. Głusi nie używają SJM, porozumiewają się w PJM. Zob. <http:// jezykowaoaza.pl/2015/03/jezyki-niezwykle-polski-jezyk-migowy/> [dostęp: 28.11.2018].

273 Estetyczne aspekty tworzenia i odbioru sztuki 
słyszą ludzie zdrowi. Specyficzna artykulacja głosek szumiących i ciszących, konieczność bezpośredniego patrzenia na twarz rozmówcy związana z czytaniem z ruchu warg czy ograniczenia w rozmowach telefonicznych rzadko spotykają się ze zrozumieniem słyszącego społeczeństwa - wywołują irytację, zniecierpliwienie, a nawet lekceważenie. Osoby aparatowane żyją gdzieś pomiędzy światem „zdrowych” a Kulturą Głuchych, nie należą w pełni do żadnego $z$ tych środowisk i często po obu stronach bywają izolowane $^{9}$. Dotyczy to także różnych aspektów uczestnictwa w kulturze i wiąże się z utrudnionym odbiorem jej artystycznych wytworów.

Wojtek Ziemilski, reżyser spektaklu Jeden gest, w którym występują aktorzy posługujący się Polskim Językiem Migowym, wprost stwierdza, że przedstawienie zrobione zostało z perspektywy kultury dominującej, którą tworzą ludzie słyszący. Zwraca uwagę zwłaszcza na wątek kolonizacyjny, który tworzy mocną hierarchię, spychając głuchych na pozycję mniejszości. Słyszący reżyser - mimo najszczerszych intencji - nie jest $\mathrm{w}$ stanie przekroczyć owej granicy. Jest świadomy, że podejmowanie tematu funkcjonowania osób niesłyszących wśród „zdrowej” większości wymaga zachowania pokory wobec obcego świata, „ostrożności” ${ }^{10}$. Doświadczenie Ziemilskiego pokazuje, że jednym z niewielu języków, który rozumieją wszyscy ludzie, zarówno słyszący, jak i niesłyszący, jest język sztuki.

Spektakl Jeden gest za pomoca teatralnych i dramatycznych środków kieruje również uwagę na bardzo istotny aspekt funkcjonowania osób z dysfunkcjami słuchu w społeczeństwie i kulturze - na ich nierozpoznawalność. Aktorzy niesłyszący niczym się nie wyróżniaja. Dopóki nie zostają wypowiedziane pierwsze słowa, widz może być nieświadomy ich głuchoty. Dopiero brzmienie głosu aktorki, która jako pierwsza wypowiada swoją kwestię, zdradza inność. Wady słuchu, zwłaszcza u osób nieaparatowanych, nie widać na pierwszy rzut oka.

Głuchota jest kondycją szczególną: nie ujawnia się w pierwszym spojrzeniu, jak paraliż czy amputowana kończyna. Tym, co może ją ujawnić, jest kontakt (gdy okazuje się, że niesłysząca osoba nie reaguje i nie mówi tak, jak można byłoby się spodziewać) albo proteza słuchu - trąbka, aparat słuchowy bądź implant ${ }^{11}$.

${ }^{9}$ Oliver Sacks, opisując historię swojej niedosłyszącej koleżanki Lucy K., cytuje jej następującą wypowiedź: „Czasami czuję się, jak gdybym była częścią dwóch światów i nie należała w pełni do żadnego" (zob. O. Sacks, dz. cyt., s. 18, przypis nr 1). Można zaryzykować stwierdzenie, że większość osób noszących aparaty słuchowe podpisałaby się pod tymi słowami.

${ }^{10}$ Zob. A. Legierska, Ziemilski: Jak zobaczyć głos, 2016, <https://culture.pl/pl/artykul/ ziemilski-jak-zobaczyc-glos-wywiad> [dostęp: 10.11.2018].

${ }^{11}$ E. Godlewska-Byliniak, Odzyskiwanie obecności. Niepetnosprawność w teatrze i performansie, Warszawa 2017, s. 251. Na ten sam problem zwraca uwagę Magdalena Dunaj w rozprawie doktorskiej GEUCHY-ŚWIAT. Gtuchota $w$ perspektywie antropologii zaangażowanej, <http://dspace.uni.lodz.pl/xmlui/bitstream/handle/11089/8015/dunaj-swiat-gluchy- 
Wymuszona konieczność bezpośredniego kontaktu ujawnia inność, ale zarazem umożliwia zupełnie odmienny (ale nie nowy!) sposób porozumiewania się - dla niesłyszących, zwłaszcza tych posługujących się językiem migowym, oczywisty ${ }^{12}$, natomiast dla słyszących znany, ale nierzadko krępujący i powszechnie unikany. Niełatwo jest cały czas spoglądać w oczy swojemu rozmówcy, być świadomym, że ktoś uważnie obserwuje mimikę twojej twarzy, widząc znacznie więcej, niż byś sobie życzył. W dodatku trzeba znajdować się w dość bliskiej odległości i pozwolić na „bycie czytanym”. Taki relacyjny sposób komunikacji może być postrzegany jako naruszenie sfery prywatnej, wejście w czyjaśs intymność, zarezerwowaną jedynie dla najbliższych. Tymczasem dla niesłyszących sytuacja spotkania jest naturalna, wręcz niezbędna do porozumiewania się, co bynajmniej nie znaczy, że nie sa oni świadomi reakcji, jakie wywołują u słyszących interlokutorów ${ }^{13}$. Niemniej, chcąc funkcjonować w świecie słyszących, podejmują się

gluchota-w-perspektywie-antropologii-zaangazowanej.pdf? sequence=1\&isAllowed=y>s. 213, [dostęp: 20.11.2018]. Ciekawym kontekstem dla dyskusji o „inności” świata Głuchych jest film Myrosława Słaboszpyckiego Plemię z 2014 roku. Opowiada historię młodego Siergieja, który trafia do internatu przy szkole dla głuchoniemych. Reżyser ukazuje wyjątkowo bezwzględny i brutalny obraz równoległej rzeczywistości, która nie różni się niczym od świata „zdrowych”, poza brakiem głosu. Ba, jest nawet znacznie bardziej szokująca. Słaboszpycki nie unika trudnych tematów - niepohamowanej agresji i bezsilności wobec niej, seksu, przemocy. Ukazuje skrajne zezwierzęcenie człowieka. Nie byłoby w tej formie nic nowego, gdyby nie fakt, że film w całości został nakręcony wyłącznie w języku migowym, bez lektora i napisów. Cisza, która uderza z ekranu, dodatkowo wzmacnia szokujące wrażenia, jakich doznaje widz bombardowany naturalistycznymi obrazami bestialstwa i bezduszności. Efekt, jaki osiaga reżyser, trafnie podsumowuje komentarz Jany Stępniewicz: „Słaboszpyckiemu udało się osiagnąć niewyobrażalny efekt tortur - kiedy patrzenie na ekran moralnie boli, a jednak nie możemy oderwać od niego oczu”. Zob. J. Stępniewicz, Bez znieczulenia. Recenzja „Plemienia” Myrosława Staboszpyckiego, <https://kulturaliberalna.pl/2015/06/16/bez-znieczulenia-recenzja-plemienia-myroslawa-slaboszpyckiego/> [dostęp: 29.10.2018].

${ }^{12}$ Zauważa to Zemilski, stwierdzając, że „głusi mają łatwiej dlatego, że w naturalny sposób skupiaja się na swoim przekazie i szukają odbiorcy, czego słyszący nie robią". Zob. A. Legierska, ,Jeden gest”, reż. Wojciech Ziemilski, <https://culture.pl/pl/dzielo/jeden-gest-rez-wojciech-ziemilski> [dostęp: 10.11.2018]. Również Dunaj podkreśla, że „ŚWIAT-GŁUCHY konstytuuje się w aktach migania. Żeby taki akt mógł mieć miejsce, potrzeba spotkania; muszą spotkać się osoby, które migają" Zob. M. Dunaj, dz. cyt., s. 165.

${ }^{13}$ Ewelina Godlewska-Byliniak rozwija ten problem, posługując się pojęciem „maskarady” zapożyczonym z teorii queerowych. Na przykładzie Josepha Grigelya, głuchego artysty plastyka zajmującego się sztuką konceptualna, przedstawia strategię, która wynika z pragnienia zamaskowania przez niego swojej inności: „Oto jego reakcja na niedawne doświadczenie w Metropolitan Museum of Art w Nowym Jorku, kiedy jeden ze strażników złapał go za ramię i udzielił mu reprymendy za to, że nie usłuchał jego polecenia powstania z podłogi, na której siedział: «Spojrzałem na siebie w lustrze, szukając oznak głuchoty, ale ich nie znalazłem. Z jakiegoś powodu przyjmujemy za pewnik to, że inność jest zjawiskiem widocznym, skoro ciało pokazuje rasę czy płeć. Być może przydałby mi się aparat słuchowy,

275 Estetyczne aspekty tworzenia i odbioru sztuki 
roli performerów codzienności, którzy nieustannie zmieniają rzeczywistość komunikacji, wywołując niespotykane reakcje, przełamując granice relacji, a nawet modyfikujac postrzeganie świata przez „zdrowych”.

Zarówno posługiwanie się językiem migowym, jak i czytanie z ruchu warg czy obserwowanie mimiki rozmówców wymagają widzenia. Wydaje się zatem, że w przypadku osób niesłyszących dominującym zmysłem percepcji jest wzrok, który w tradycji estetycznej uważany był za jeden ze zmysłów kontemplacyjnych, budujących dystans wobec dzieła sztuki ${ }^{14}$. Tymczasem głusi, tak samo jak wszyscy słyszący, postrzegają świat polisensorycznie, odbierając bodźce ze wszystkich ośrodków zmysłowych - słuchowe także. $\mathrm{Na}$ ten problem zwraca uwagę Arnold Berleant:

Zwodzi nas myśl, że ponieważ różne zmysły mają swoją siedzibę w określonych organach lub obszarach ciała, to będziemy w stanie rozróżnić ich sygnały w konkretnych sytuacjach percepcyjnych. Umiejętność rozróżnienia danych otrzymywanych dzięki receptorom różnych zmysłów bierze się jednak z selektywnego doświadczenia oraz refleksji i nie jest aktem spontanicznego rozpoznania. Przeciwnie, najczęściej kilka, lub nawet wszystkie zmysły są zaangażowane w percepcję, chociaż z reguły ten fakt może nas zaskakiwać, gdy w wyniku upośledzenia któregoś z organów zmysłów to szeroko rozpowszechnione przekonanie okazuje się błędne ${ }^{15}$.

Widzenie analizowane z perspektywy osób niesłyszących w szczególny sposób podważa koncepcję istnienia zmysłów dystansu (wzroku i słuchu). Powiązane jest z wymiarem ściśle cielesnym, sprzężone $\mathrm{z}$ wykonywanym gestem (miganie) i obserwowaniem poruszeń twarzy (czytanie z ruchu warg, rozpoznawanie stanów emocjonalnych). Zatem percepcja sztuki - zarówno tej, która jest odbierana przez osoby z wadami słuchu, jak i tej, która jest przez nie tworzona - także zyskuje rys bardziej materialny, cielesny. W akcie wzajemnego spotkania niesłyszacy (odbiorca lub twórca) dotyka wzrokiem swojego partnera estetycznej komunikacji. Ów dotyk, jak już

nie taki w kolorze cielistym, ale taki czerwony [...] element, który ceremonialnie obwieści światu swoje znaczenie». Grigely porównuje owo pragnienie zamanifestowania swojej głuchoty do opresyjnej praktyki polegającej na wieszaniu tabliczki z napisem «ŚLEPY/A» na szyjach osób niewidomych. Czuje potrzebę, żeby ujawnić swoją niepełnosprawność po to, aby nie wprawiać osób sprawnych w zakłopotanie, co zagwarantuje mu jednocześnie niewidoczność". Zob. E. Godlewska-Byliniak, dz. cyt., s. 82-86, 190.

${ }^{14}$ Por. A. Berleant, Prze-myśleć estetykę. Niepokorne eseje o estetyce $i$ sztuce, przeł. M. Korusiewicz, T. Markiewicz, red. K. Wilkoszewska, Kraków 2007, s. 102-103.

${ }^{15}$ Tamże, s. 104. Autorka rozprawy GEUCHY-ŚWIAT... także zauważa polisensoryczne postrzeganie świata przez osoby niesłyszące: „Umiejętności głuchych związane są z intensywnym korzystaniem ze wszystkich dostępnych zmysłów. Nieskupianie się tylko na słyszeniu stwarza możliwość równorzędnego traktowania informacji pochodzących z różnych źródeł, w tym z własnego ciała. Zaufanie do tego, co się widzi i odczuwa, pozwala głuchym być kierowcami, budowlańcami czy operatorami maszyn”. Zob. M. Dunaj, dz. cyt., s. 213. 
wspomniałam, bywa równie intymny, wytrącający ze strefy prywatności, jak kontakt skóry ze skóra. Zmusza do bezpośredniej interakcji z twórca i jego dziełem, wymaga zaangażowanego uczestnictwa ${ }^{16}$.

\section{Zobaczyć dźwięki}

Patrząc z perspektywy osoby słyszącej, można stwierdzić, że już samo miganie jest sztuką - swoistą pantomima języka, być może niezrozumiałą na płaszczyźnie kodu, ale fascynująca w swej płynności i przestrzenności. Anna Legierska w rozmowie na temat spektaklu Jeden gest porównuje ów ruch do swoistego tańca. Podkreśla przy tym, że znaczy on o wiele więcej niż gest teatralny, a jednocześnie zostaje „uteatralniony” w spektaklu ${ }^{17}$. Ziemilski, wykorzystując język migowy jako temat i tworzywo, buduje wielopoziomową dramatyczność, gdzie gest nie tylko jest równoważny słowu, ale stanowi hybrydę znaczenia, ruchu i języka, coś niebywałego i niemożliwego do osiagnięcia w zwykłym spektaklu, nawet awangardowym. Ewelina Godlewska-Byliniak natomiast doszukuje się w potencjale tegoż języka znamion performatywności:

Właśnie ta przestrzenność, ruch, jego dynamika i wielokierunkowość są tym, co stanowi performatywną siłę tego języka. [...] Jeśli możemy tu mówić o choreografii, to niewątpliwie nie tylko o jej aspekcie estetycznym, ale też społecznym. Intrygującym efektem tej choreografii, pojawiającym się być może na marginesie spektaklu, ale niemniej intrygującym, jest to, w jaki sposób wprawia ona w ruch inne rejestry języka i komunikacji, każąc zastanowić się nad ich nie-oczywistością ${ }^{18}$.

Język migowy pozwala na znacznie więcej niż wzajemne porozumiewanie się czy opowiadanie historii. Swoje możliwości ujawnia między innymi w choreografii miganych utworów muzycznych oraz podczas „recytacji” miganej poezji. Obie te formy artystyczne opierają się na odpowiednich sekwencjach ruchu. W pierwszym oglądzie mogą wydawać się niemal identyczne, ale po dokonaniu głębszej analizy ujawniają się znaczące różnice.

\section{Pomost}

Poezja migana stanowi połączenie twórczego działania myśli z ekspresyjnym tańcem ciała. Każda poza, gest, sposób poruszania dłońmi czy pal-

\footnotetext{
${ }^{16}$ Por. A. Berleant, dz. cyt., s. 157-159.

${ }^{17}$ Por. A. Legierska, „Jeden gest”...

${ }^{18}$ E. Godlewska-Byliniak, dz. cyt., s. 195-196.
} 
cami są znaczące i składają się na pełny obraz estetycznego przekazu. Ciało poety jest zarazem artykulatorem (narzędziem), tworzywem utworu, jak i częścią samego aktu twórczego. W żadnym innym przypadku - może poza performasem - artysta i jego dzieło nie stapiają się w tak integralną jedność. Porównywanie tej twórczości do jakiejkolwiek poezji słownej może odbywać się jedynie na płaszczyźnie emocjonalnej, jednakże cielesność i sensualność poruszeń zbliża prezentowany rodzaj sztuki do tańca lub pantomimy.

Wiersze migane, ze względu na specyfikę języka migowego, mają charakter wizualny. Nie wyklucza to jednak ich gatunkowości. Wyróżnia się poezję kształtu polegająca na utrzymywaniu podczas migania kolejnych znaków wybranego kształtu dłoni, poezję $\mathrm{ABC}$ budowaną w oparciu o cały alfabet (kształt dłoni zmienia się według sekwencji od A do Z), poezję imienną tworzoną na zasadzie literowania czyjegoś imienia lub nazwiska (przeważnie autora), poezję liczbową wykorzystująca liczebniki (podobnie jak w przypadku poezji $\mathrm{ABC}$ kształt dłoni zmienia się sekwencyjnie według kolejności liczebników, na przykład od 1 do 10) oraz pokazy poetyckie oparte na innej sekwencji znaków (na przykład miesiące, dni tygodnia) ${ }^{19}$. Z perspektywy osoby słyszącej wydaje się, że konstruowanie całego utworu z pojedynczych rozumianych w kontekście języka mówionego - słów czy liter wydaje się zbyt proste, krótkie, może nawet dziwne. Tymczasem ciagi znaków, które pozwalają na klasyfikację wierszy miganych, stanowia jedynie punkt wyjścia, podstawę językowa, na której opiera się cały przekaz.

Kluczowa dla zrozumienia tego, w jaki sposób za pomoca „konkretnych” reprezentacji ikonicznych możliwe jest wyrażanie abstrakcyjnych treści w językach migowych, jest koncepcja podwójnego mapowania: metaforycznego i ikonicznego. Oznacza to, że przynajmniej część znaków w językach migowych, a także struktur składniowych jest motywowana zarówno ikonicznie, jak i metaforycznie ${ }^{20}$.

Poeta dodaje do nich płynny, taneczny ruch całego ciała, powtarzalny w różnych układach, mimikę twarzy, swój indywidualny, charakterystyczny sposób migania - swoją osobowość. To wszystko sprawia, że na podstawie tych samych znaków mogą powstać setki różnych wierszy wyrażających skrajnie odmienne emocje ${ }^{21}$. Co więcej, niektóre układy wierszy powstaja spontanicznie, na bieżąco, pod wpływem nastroju, natchnienia, transu ${ }^{22}$. To nadaje poezji miganej rys performatywny, gdyż oglądający staje się świad-

${ }^{19}$ Zob. Poezja migana, <http://pzg.warszawa.pl/poezja-migana/> [dostęp: 25.11.2018].

${ }^{20}$ M. Dunaj, dz. cyt., s. 147.

${ }^{21}$ Przykładem różnorodności poezji miganej są utwory wykonywane przez Arkadiusza Bazaka: zob. A. Bazak, Poezja Migana, 2014, <https://www.youtube.com/ watch?v=XxxpXwwgHwU> [dostęp. 15.11.2018].

${ }^{22}$ Dunaj podkreśla, że: „Mechanizm ikoniczności przywołuje kwestię powtórzenia. Powtarzanie konstytuuje praktykę. Powtarzanie zapewnia trwanie w czasie, ma funkcję spaja- 
kiem bezpośrednich narodzin nowej opowieści, która może się już nigdy nie powtórzyć. W tej liryce jest coś nieuchwytnego dla odbiorcy „z zewnątrz”, jednak nieznajomość języka migowego nie utrudnia odbioru w takim stopniu, by nie odczuć ekspresyjnego ładunku i nie docenić widzialnego piękna pokazu ${ }^{23}$.

Co prawda znaczenie poszczególnych gestów poetyckich jest nieprzekładalne, jednak niektóre z miganych znaków moga przypominać naśladowanie znanych kształtów, co jest czytelne dla wszystkich oglądających, zarówno głuchych używających innych języków niż PJM, jak i osób słyszących. Miganie pantomimiczne (Visual Vernacular ${ }^{24}$ ) stanowi istotny składnik utworów lirycznych tworzonych za pomocą gestów.

Jest to teatralna forma opowiadania historii w naturalnym języku migowym z silnym wyczuciem ruchów ciała, znaków, gestów, ekspresji twarzy. [...] Opowiada się historię w sposób bardziej wizualny niż treściowy. Słuchacz oglądający opowieść w VV jest w stanie odtworzyć opowiadaną historię w wyobraźni w postaci obrazu niemal tak, jakby oglądał film ${ }^{25}$.

Taka forma wyrażania poetyckiej ekspresji pozwala również na przekładanie wierszy słownych na język migowy. Jednym z tłumaczy i ambasadorów poezji miganej jest Arkadiusz Bazak, który migał między innymi wiersze Zbigniewa Herberta, Tadeusza Różewicza, Adama Mickiewicza i Juliusza Słowackiego. Miganie pantomimiczne „nie tylko pokazuje piękno języka ciała i gestów, który jest integralną częścią świata Głuchych, ale też może stanowić most między tym światem a światem osób słyszących" ${ }^{26}$.

jąca. Jednocześnie w powtarzanie wpisana jest możliwość twórczej kreatywności” (M. Dunaj, dz. cyt., s. 148).

${ }^{23}$ Trafnie ujmuje problem Wojtek Ziemilski, relacjonując swoje wrażenia po kontakcie z poezją migana, której mistrzem był aktor występujący w spektaklu Jeden gest. Reżyser stwierdza, że „poezja migana, poezja wizualna jest specyficznym rodzajem pantomimy, zrozumiałej tylko dla głuchych. Adam wygrał ogólnopolski konkurs poezji migowej, ale ja nie do końca potrafię docenić jego kunszt. Przecież nie wiem, jak to jest stworzyć całą opowieść, używając tylko jednej formy dłoni, jednej litery. Dopiero po miesiącu pracy z nim zaczynam rozumieć, jak wybitnym znawca języka trzeba być, jak świetnym performerem, żeby coś takiego wykonać. Dla zwykłego widza to po prostu pantomima, znaki przekształcajace się w postaci z danej opowieści. A tymczasem to sztuka, którą mogę porównać do iluminacji w średniowiecznych rękopisach. Jest formą graficznej pracy nad językiem. To jest świat, który rządzi się swoimi prawami. Ma swoje wartości, które z zewnątrz trudno docenić. Tak, jak w naszej poezji forma dytyrambu czy dwunastozgłoskowca przestała już być czymś, co cenimy. Można powiedzieć - intrygujące, ale nie jest dla nas ważne, ale dla innej kultury może być. Tak odbieram poezję wizualną". Zob. A. Legierska, Ziemilski: Jak zobaczyć głos...

${ }^{24}$ Dalej jako VV.

${ }_{25}$ „Miganie pantoMimiczne - magia języka migowego”(Visual Vernacular), <http://pzg. warszawa.pl/miganie-pantomimiczne/> [dostęp:18.11.2018].

${ }^{26}$ Zob. A. Bazak, „Żegluga”. Warsztaty poezji miganej, 2018, <http://literatura.wroclaw. pl/wydarzenia/zegluga-warsztaty-poezji-miganej/> [dostęp: 18.11.2018]. 
Wydaje się, że podobną funkcję może spełniać teatr, w którym elementy pantomimy nierzadko stanowia podstawowe tworzywo artystyczne. Spektakl Jeden gest, wnikliwie analizowany przez Godlewską-Byliniak ${ }^{27}$, może potwierdzać to założenie. Badaczka podkreśla, że „w przypadku spektaklu Ziemilskiego obecność osób Głuchych w istotny sposób wpływa na teatralny język, nie tylko wprowadzając do niego nowa jakość estetyczna, ale też wymuszając poszukiwanie nowych form wyrazu"28. Warto dodać - takich, które łączą dwa bardzo zbliżone, ale niezrozumiałe dla siebie światy.

Z perspektywy osoby słyszącej i nieznającej języka migowego kontakt z osobą migająca, szczególnie w przestrzeni teatru, który nie tylko zezwala na bezkarne gapienie się, ale wręcz to zakłada, może prowadzić do swoistego oszołomienia czy oczarowania performatywną siła gestu, który jest nieprzezroczysty znaczeniowo, a jednocześnie nośny na poziomie oddziaływania afektywnego.

[...]

Gest rozumiem tutaj nie jako uzupełnienie mowy, gestyczny dodatek do niej, wzmocnienie jej sensu, ale jako cielesny znak i działanie w całej jego złożoności kinestetycznej i znaczeniowej. To on wprowadza zakłócenie w obrębie percepcyjnych przyzwyczajeń tych, którzy zazwyczaj swoją relację ze światem i rozumienie samego siebie opierają na kategorii słuchu i związanego z nim głosu ${ }^{29}$.

Ekstremalna forma kontaktu bezpośredniego, którą stanowi dramatyczne spotkanie na scenie, jest jednak niepełna. Aktorzy migający sa początkowo oddzieleni od widowni ścianą. Widać jedynie poruszające się ręce. Efekt, jaki osiaga reżyser, bardzo trafnie charakteryzuje zarówno relacje między światem słyszących a głuchymi, jak i pomiędzy ludźmi w ogóle. Fizycznie istniejąca bariera w spektaklu Ziemilskiego po pewnym czasie znika i widz może zobaczyć tych, którzy do niego mówią. Ten gest zyskuje wymiar symboliczny nie tylko w sensie komunikacyjnym, ale także jako wizualizacja doświadczeń niesłyszącego odbiorcy w teatrze. Niewidzialna ściana przed sceną w większości przypadków nie znika. Dowodem na to mogą być doświadczenia niesłyszącej teatrolożki:

Teraz chyba czas na największy paradoks, jeśli chodzi o mój odbiór kultury i kłopoty z nim związane. Jestem absolwentka teatrologii. [...] Oczywiste jest, że [...] podstawa studiów teatrologicznych sa przedstawienia teatralne. A z tym były i sa pewne problemy. [...] Czasem można było się posiłkować tekstem dramatu, akurat wystawianym na scenie, ale to wyjątkowa sytuacja. [...] Zdarzały mi się takie wizyty w teatrze, z których wychodziłam niepewna swoich wrażeń i niekomentująca w ogóle przedstawienia właśnie dlatego, że nie usłyszałam dobrze jakiejś części [...] wypowiedzi aktorów! Dlatego też bardzo cenię sobie te spektakle, które od-

\footnotetext{
${ }^{27}$ Zob. E. Godlewska-Byliniak, dz. cyt., s. 183-196.

${ }^{28}$ Tamże, s. 195.

${ }^{29}$ Tamże, s. 185, 190.
} 
chodzą od słowa, warstwy werbalnej jako dominanty w stronę działań fizycznych, bezpośrednich interakcji czy po prostu działania na scenie, próby zastapienia dialogu innymi elementami teatralnymi. Oczywiście większość przedstawień łączy te wszystkie elementy i często trudno jest zastapić słowo, dialog czymś innym, bo ono samo w sobie jest akcja, jest sednem historii [...], jednak widziałam też spektakle, w których warstwa słowna była ograniczona do minimum, zaś kolejne sekwencje ruchów i interakcji artystów połączone z muzyką niekiedy wywoływały więcej wrażeń oraz „opowiadały” więcej niż same słowa. [...] Żebyśmy dobrze się zrozumieli: to nie tak, że w ogóle nie jestem w stanie dobrze usłyszeć aktorów na scenie, ale jest wiele czynników, które utrudniają mi pełne ich zrozumienie: muzyka lub inne dźwięki, odległość od sceny, ustawienie aktorów i ich własne interakcje ${ }^{30}$.

Podobne problemy dotykają większość osób niesłyszących, jednak w szczególnej sytuacji znajdują się ci, którzy nie znają języka migowego i funkcjonują jedynie dzięki aparatom słuchowym. Jednym z najprostszych sposobów ułatwienia percepcji dźwiękowych spektakli teatralnych dla takich widzów są napisy, które mogą być wyświetlane na przykład na rzutnikach czy ekranach, jak to nierzadko ma miejsce na scenach operowych. Technicznym rozwiązaniem może być również zainstalowanie pętli indukcyjnych ${ }^{31}$, które poprawiają słyszenie, tłumiąc wokół niepożądane dźwięki. Ta metoda ma jednak swoje wady, gdyż odbiór w pętli zależy od rodzaju wady słuchu, jakości aparatu, a nawet sposobu udźwiękowienia sceny (część istotnych dźwięków również może zostać wytłumiona). Można wreszcie iść w ślady Ziemilskiego przestać izolować niedosłyszących i produkować więcej spektakli zrozumiałych dla wszystkich. Każde z tych rozwiązań może osłabić bariery odbiorcze i otworzyć teatr na nowe formy. Wystarczy postawić się w pozycji Innego.

\section{Poczuć muzykę}

Berleant, pisząc o roli zmysłów w doświadczeniu estetycznym, stwierdza, że muzyka jest dziedziną sztuki, którą łatwiej dopasować do tradycyjnych

${ }^{30}$ E. Pakalska, dz. cyt.

${ }^{31}$ „Pętle indukcyjne są systemem wspomagającym słyszenie u osób słabosłyszących, korzystających z aparatów słuchowych. Nie emitują one dźwięków, a zmienne pole magnetyczne przekazywane do aparatu słuchowego, gdzie zamieniane jest na dźwięk. W ten sposób eliminowany jest hałas i inne niekorzystne warunki akustyczne, co w znacznym stopniu poprawia zrozumiałość mowy i czytelność dźwięków. [...] Należy pamiętać, że nagłośnienie sali czy głośniki w eksponacie bardzo często nie dają osobie korzystającej z aparatu słuchowego żadnych korzyści”. Zob. K. Kowalski, Architektura i rozwiazania techniczne, [w:] ABC Gość niepetnosprawny $w$ muzeum, „Szkolenia Narodowego Instytutu Muzealnictwa i Ochrony Zbiorów" 2013, 2, s. 44.<https://www.nimoz.pl/files/publications/17/ABC_Gosc_niepelnosprawny_lekki.pdf> [dostęp: 26.11.2018], Czym jest pętla indukcyjna?, <https://petlaindukcyjna.pl/ czym-jest-petla-indukcyjna/> [dostęp: 26.11.2018]. 
teorii estetycznych optujących za zachowaniem percepcyjnego dystansu. By ukazać złożoność jej doświadczania, odwołuje się do „wizualnego spektaklu” wykonywania utworów muzycznych ${ }^{32}$ lub do koncepcji „estetycznego ucieleśnienia"33. Tymczasem specyficzny sposób odbioru melodii przez osoby z wadami słuchu wymusza zredukowanie wszelkich form dystansu, pozwala zatem na uznanie muzyki za sztukę polisensoryczną bez odwoływania się do wizualnych konotacji.

Trudno wyobrazić sobie, że głusi, nawet ci niesłyszący od urodzenia, używający PJM, również słuchają muzyki, a nawet ją tworza. Ubytek słuchu znacząco wpływa na sposób percepcji, ale jej nie wyklucza. Podobnie jak w przypadku osób niedowidzących ważny i pożądany jest wyraźny kontrast barwny, tak odbiorcy niedosłyszacy zwracają uwagę na brzmienia mające wyraźny rytm i powtarzalność. Dźwięku co prawda nie można zobaczyć (przynajmniej w codziennych warunkach), ale można go poczuć. Uderzenia fali dźwiękowej, wibracje, drżenie nośnika są odczuwalne zarówno przez ludzi zdrowych, jak i tych, którzy słyszą słabiej lub w ogóle. Sekwencyjne partie akustyczne - nawet bardzo uproszczone - dają wrażenie harmonii i częściej postrzegane sajako coś wartego oceny, przemyślenia. Natomiast dysharmonie i foniczne przemieszczenia bywają uznawane po prostu za hałas. Taki sposób percypowania może znacząco wpływać na odbiór sztuki, w której głównym tworzywem jest dźwięk, warunkując jej interpretację i estetyczne wartościowanie. Widać to szczególnie na przykładzie utworów muzycznych, ale nie tylko.

W zależności od rodzaju wady słuchu osoby niesłyszące preferują dźwięki niskie lub wysokie. Odbiór poszczególnych dzieł zatem w znacznym stopniu zależy od technicznych parametrów słyszenia, co sprawia, że wybrane gatunki muzyczne moga być bardziej zrozumiałe i słyszalne od innych. I tak muzyka klasyczna, ze względu na swoją rytmiczność i harmonijny rozwój tematu, potencjalnie będzie bardziej doceniana niż tony awangardowe. Brzmienia elektroniczne z wyraźną ścieżką rytmiczną i rozwiniętym basem wydają się lepiej słyszalne i rozpoznawalne niż jazz czy rock (szczególnie trudne w odbiorze przez obecność szumów i riffów, które podlegają dodatkowym mechanicznym zniekształceniom w mikrofonach aparatów słuchowych i moga wywoływać akustyczne sprzężenia). Osoby z dysfunkcjami słuchu także częściej wybierają muzykę instrumentalną niż śpiew, który przez niestandardową modulację i akcentowanie bywa niezrozumiały, a ponadto zakłóca w pewnej mierze odbiór poszczególnych ścieżek dźwiękowych. W takiej optyce tekst piosenki ma znaczenie drugorzędne, natomiast na pierwszy plan

${ }^{32}$ A. Berleant, dz. cyt., s. 104.

${ }^{33}$ Zob. tamże, s. 113. Autor Wrażliwości i zmysłów przywołuje przykład muzyki programowej, która sugestywnie oddaje (ucieleśnia) różne wrażenia emocjonalne, a nawet ilustruje pewne działania, oddaje ich dynamikę, złożoność. 
wysuwa się barwa i siła głosu, które przejmują rolę estetycznej dominanty, decydując o tym, czy utwór się podoba czy nie. Ten sam problem ujawnia się także w przypadku tekstów recytowanych, spektakli teatralnych czy filmów.

Analiza pewnego przypadku osoby aparatowanej z głębokim, obustronnym niedosłuchem ukierunkowanym na dźwięki wysokie dała nietypowe wyniki muzycznych preferencji, które u osoby zdrowej mogłyby wywołać zaskoczenie. Badany mężczyzna wybierał utwory elektroniczne o wyraźnie prowadzonym basie i sekwencyjnej rytmice (techno, disco, muzyka klubowa), określając ów rytm jako dobrze słyszalny i niemęczący ucha. Unikał zdecydowanie utworów śpiewanych, poza jednym wyjątkiem - opera. Silne natężenie dźwięku oraz subtelna modulacja bez gwałtownych przeskoków rytmicznych pozwalała bez problemu odczytywać emocje i wczuwać się w klimat dzieła. Oczywiście nie można pominąć kwestii osobistej wrażliwości muzycznej danej osoby, która z pewnością wpłynęła na wybór utworów. Warto jednak zauważyć, że to niecodzienne zestawienie preferencji muzycznych nie tylko pokazuje różnice w percepcji muzyki przez osoby niedosłyszące, ale przełamuje również - być może w niezamierzony, ale wyraźny sposób - pewna sztywność podziałów gatunkowych, owo wciąż popularne rozróżnienie na kulturę wysoką i niską. Okazuje się, że wystarczy zmienić perspektywę, by przesunąc rzekomo istniejące granice.

Natomiast autorka bloga I'm not there otwarcie przyznaje, że nie interesuje się muzyka, choć stara się mimo wszystko mieć jakiś kontakt ze światem muzycznym.

Jakże zazdrościłam ludziom, że potrafią wzruszać się muzyka, słyszeć tekst piosenki „zatopionej” w melodii, wyłowić melodię konkretnego instrumentu, rozpoznać motyw przewodni w ścieżce dźwiękowej.. Wydawało mi się, że takie rzeczy są zupełnie niedostępne dla nie(do)słyszących [...]. Teraz wiem, że to nie do końca prawda [...]. W moim przypadku nacisk został położony przede wszystkim na poprawność mówienia i wczesną naukę pisania i czytania. To oczywiście okazało się bardzo cenne, jednak nierzadko miałam wrażenie, że w niezamierzony sposób zostałam czegoś pozbawiona, na przykład wrażliwości muzycznej czy osłuchania się w językach obcych [...]. Żeby jednak móc jakoś odbierać muzykę, przez jakiśs czas namiętnie oglądałam teledyski, by w ten sposób móc chociaż wyobrazić sobie, o czym jest dana piosenka ${ }^{34}$.

Receptą na problemy z rozumieniem tekstu czy linii melodycznej stały się obrazy. Wizualna ekspresja teledysków przejęła wartość znaczeniową tekstu. Podobnie dzieje się w przypadku tworzenia muzyki miganej. „Jeśli chcesz się przekonać, jak osoba niesłysząca czuje dźwięki, to włóż stopery w uszy, włącz muzykę i poczuj wibracje - mówi Damian Olak

${ }^{34}$ E. Pakalska, dz. cyt. 
z grupy Młodzi Migają Muzykę (MMM)" ${ }^{35}$. Miganie muzyki, w przeciwieństwie do poezji miganej, oparte jest przede wszystkim na fizycznym odczuciu dźwięku oraz autorskich interpretacjach tekstów piosenek. Nie sa to jednak tylko tłumaczenia warstwy słownej. Brzmienie bezpośrednio dotyka migających, odbierane jest całym ciałem i wszystkimi dostępnymi zmysłami. To sprawia, że czujący przeżywa doświadczenie totalne, które przenosi później na migany tekst. Migane piosenki mają wyraźnie widoczną warstwę rytmiczna. Ich wykonania, nawet w większym stopniu niż poezja, przypominają taniec. Można zaryzykować stwierdzenie, że sa tańcem - tańcem znaków snujących opowieść i interpretujących melodię. Potencjał miganej muzyki, która u słyszących może wywoływać wrażenie zwielokrotnienia ekspresji (wyrażanej zarówno przez tradycyjnie rozumiane dźwięk oraz słowa, jak i przez znaczące poruszenia ciała migajacych), wykorzystał między innymi zespół Video, który podjął współpracę z grupa MMM przy tworzeniu jednego z teledysków ${ }^{36}$. Młodzież tłumaczyła również koncerty formacji ${ }^{37}$.

Przekładanie brzmień na obrazy może przyjmować także bardziej dosłowną formę. Taki właśnie był temat wystawy Grupy Artystów Głuchych „Bez-dźwięk to sztuka”, która odbyła się 9 lutego 2018 roku w Katowicach. Prace prezentowane na wernisażu skupiały się wokół zagadnienia widzialności dźwięku i jego plastycznych realizacji.

Intrygujące jest to, w jaki sposób osoby niesłyszace przedstawiają świat dźwięku dla nich kompletnie abstrakcyjny, prawda? Poprzez prace z zakresu malarstwa, fotografii, grafiki, ilustracji oraz poezji artyści pokazuja, jak słysza, widzą i czują muzykę. Dla niesłyszących osób sztuką jest wewnętrzne odczuwanie muzyki jako wibracji. Wibracje są subiektywne, właściwe dla danego artysty zależnie od stopnia słyszenia dźwięków. Interpretacja jest bardzo osobista, indywidualna i taka się pojawia w obrazach zaprezentowanych na wystawie ${ }^{38}$.

Z punktu widzenia fizyki dźwięk jest falą. Większość ludzi słyszących, myśląc o graficznym obrazie muzyki, wyobraża sobie wizualizacje i wykresy, które można zobaczyć w popularnych programach do jej odtwarzania, ewen-

${ }^{35}$ A. Greniuk, Cisza petna dźwięków, 2015, <http://www.niepelnosprawni.pl/ledge/x/251046> [dostęp: 26.11.2018].

${ }^{36}$ Zob. <https://www.youtube.com/watch?v=XlLKOeHwK7s> [dostęp: 26.11.2018].

${ }^{37}$ Wojciech Łuszczykiewicz, lider zespołu, skomentował ową współpracę następująco: „Proszę sobie wyobrazić dużą scenę i kilka czy kilkanaście tysięcy osób pod nią. Na «wybiegu» śpiewam ja, a obok stoi ktoś z Młodych i miga teksty piosenek. I w tym momencie przestajemy być gwiazdami! Gwiazdami są oni - młodzi, którzy migają. Oni się bujaja, skacza, ludzie klaszcza, bo uczymy ich jak klaskać w polskim języku migowym. Jest absolutny szał!". Zob. A. Greniuk, dz. cyt.

${ }^{38}$ O. Koczorowski, Po wernisażu wystawy GAG w Katowicach, 2018, <http://www.gag. art.pl/2018/02/wernisazu-wystawy-gag-katowicach/> [dostęp: 16.11.2018]. 
tualnie widzialność melodii przybliża tak zwane widmo akustyczne ${ }^{39}$. Tymczasem w artystycznych realizacjach autorów wystawy dźwięk przyjmuje rozmaite formy - od abstrakcyjnych kompozycji aż po figuratywne sceny. Ma twarze i kolory. Po części wynika to z wizualno-przestrzennej specyfiki języka migowego. Dla jego użytkowników powiązania między odczuwaniem wrażeń dźwiękowych, znaczeniem znaków i ich przestrzenna, widzialną realizacją są zupełnie naturalne. Słyszący natomiast bardzo rzadko łączą estetyczne doznania towarzyszące odbieraniu muzyki z obrazowym wyobrażeniem jej formy. Jeśli już pojawia się takie skojarzenie, to dotyczy raczej wspomnieniowych scen przywoływanych przez dane brzmienie i nie ma bezpośredniego związku z „wyglądem” słuchanej melodii. Prace Grupy Artystów Głuchych wprowadzają zatem nowa perspektywę interpretacji utworów muzycznych i wkraczaja do eksperymentalnej sfery sztuki synestezyjnej, wielozmysło$w j^{40}$. Potrzebę poszerzania wpływów tego rodzaju działań artystycznych zauważył już Berleant, stwierdzając, że „charakteryzowanie sztuki za pomocą zmysłu, dzięki któremu jest postrzegana - jak w przypadku nazywania muzyki sztuką dla słuchu, a malarstwa sztuką wizualną - prowadzi do dużego zafałszowania doświadczenia estetycznego" ${ }^{41}$. W podobnym tonie wypowiada się Ewa Pakalska, podkreślając, że jej własne doświadczenia [związane z niedosłuchem - E.W-Cz.] w większym stopniu uwrażliwiają jej percepcję na różne spięcia, negocjacje oraz narracje toczące się na styku niepełnosprawności i sztuki, jednakże, niezależnie od tego, dostrzega także uniwersalną potrzebę wielozmysłowego odczuwania, sensualnego doświadczania rzeczywistości ${ }^{42}$. To właśnie owo pragnienie - wspólne dla wszystkich - stoi u podstaw odwagi do przekraczania percepcyjnych granic sztuki.

${ }^{39}$ Zob. G. Szwoch, Analiza dźwięków muzycznych, 2018, <https://sound.eti.pg.gda.pl/ student/akmuz/02-Analiza.pdf> [dostęp: 16.11.2018].

${ }^{40}$ Ciekawym kontekstem do wystawy „Bez-dźwięk jest sztuką” jest praca polskiej artystki Maess (Małgorzaty Skrzypek) zatytułowana Ilustracja Dźwięku, prezentowana między innymi na wystawie w nowojorskim Drawing Center. Zadaniem każdego z zaproszonych twórców było odniesienie się do wybranych fragmentów powieści The Intuitionist Colsona Whiteheada. Rysunek Maess jest obrazem głosu wypowiadającego jedno zdanie ze wspomnianego utworu. „Artystka skompilowaną wcześniej w programie graficznym całość, będącą ilustracją rytmu, fal dźwiękowych i wygenerowanych brył 3D, przeniosła odręcznie markerem na papier" (zob. A. Kijewska, Jak narysować dźwięk?, <https://www.vice.com/pl/article/mvz8dy/jak-narysowacdzwiek> [dostęp. 16.11.2018]. Świat muzyki inspiruje również mysłowicką artystkę Nadię Świerczynę, która stworzyła serię abstrakcyjnych obrazów na podstawie utworów Henryka Mikołaja Góreckiego. Zob. M. Odziomek, Dźwięk zaklęty w obrazach, czyli malarstwo zdobywczyni „,artNobla 2015”, <http://katowice.wyborcza.pl/katowice/1,35018,19604370,dzwiek-zaklety-w-obrazach-czyli-malarstwo-zdobywczyni-artnobla.html> [dostęp: 16.11.2018].

${ }^{41}$ A. Berleant, dz. cyt., s. 104.

${ }^{42}$ To stwierdzenie podsumowuje wielogodzinne dyskusje (zarówno naukowe, jak i towarzyskie), które prowadziłam z Ewą Pakalską na temat postrzegania świata i sztuki przez 


\section{Tylko ruchome obrazy}

Wydaje się, że dla osób niesłyszących muzyka, pozbawiona widzialnej warstwy, jest najtrudniejszą w odbiorze formą sztuki. Tymczasem - paradoksalnie - największe problemy percepcyjne stwarzają dzieła, w których dźwięk ściśle wiąże się z projekcją obrazu. Najlepszym ich przykładem sa polskojęzyczne filmy kinowe lub zagraniczne filmy dubbingowane. Teoretycznie najprostszymi rozwiązaniami niedogodności odbiorczych sa: obecność tłumacza języka migowego (dla osób posługujących się PJM) oraz zastosowanie cewek indukcyjnych (dla korzystających z aparatów słuchowych).

Pierwszy sposób sprawdzałby się całkiem dobrze, gdyby na szerszą skalę zatrudniano tłumaczy PJM w kinach i innych instytucjach kulturalnych, które wyświetlają przekazy filmowe. Istnieją placówki takie jak Muzeum Ślaskie w Katowicach, które oferuja różne formy pomocy dla osób niepełnosprawnych - niewidomych, głuchych ${ }^{43}$, z trudnościami w poruszaniu się i ciagle poszerzaja zakres działań integracyjnych, jednak wciąż stanowią one wyraźna mniejszość. Szczególnie w kinach współpraca z tłumaczami PJM dopiero raczkuje.

Drugie udogodnienie ma znacznie więcej mankamentów, ale paradoksalnie nie są one związane z technicznymi aspektami działania pętli. Największym problemem jest nienajlepsze udźwiękowienie polskich produkcji filmowych, potęgowane przez równie kiepską akustykę kinowych sal. Odbiór utrudniają też niedostatki warsztatowe aktorów: słaba dykcja, niedbały sposób mówienia (wyraźna i czytelna artykulacja nie wymaga przesadnej mimiki twarzy, wystarczy swobodne tempo mówienia), a także charakterystyczne nawyki i maniery wpływajace na szybkość wysławiania się. Niebagatelne znaczenie ma nawet modulacja głosu. Pozostaje zatem znalezienie trzeciego rozwiązania.

osoby w różnym stopniu nie(do)słyszące. Za inspiracje, uwagi i ciekawe spostrzeżenia serdecznie jej dziękuję.

${ }^{43}$ Żórawska przywołuje też przykład broszury Dźwięki Powstańczej Warszawy przygotowanej dla Muzeum Powstania Warszawskiego, która zawiera zapisy i opisy dźwięków znajdujacych się na ekspozycji. „Takie rozwiązanie ma uzasadnienie w miejscu pełnym dźwięków, które zgodnie z zamierzeniem projektantów ekspozycji stanowia jej integralną całość, jak chociażby bijące serce Warszawy. «Już od progu muzeum słyszymy dźwięk bijącego serca - niski, miarowy. Jego źródłem jest wielki stalowy monument, upamiętniający Powstanie Warszawskie - ludzi i czas. To serca Muzeum. Dotknijmy. Pod palcami wyczujemy dudnienie, wibracje... 63 uderzenia na minutę, jedno uderzenie na każdy dzień powstania. Serce Powstania bije powoli, jest zmęczone». (fragment broszury «Dźwięki Walczącej Warszawy» [...] przygotowany w 2010 roku przez Fundację Dzieciom «Zdążyć z Pomocą» w ramach projektu Muzeum «Poza Ciszą i Ciemnością» [...])”. Zob. A. Żórawska, dz. cyt., s. 56. 
Można zaryzykować stwierdzenie, że wszystkie te bariery odbiorcze znikają w zapisie. Czy rzeczywiście? Tworzenie napisów dla niesłyszących do filmów dźwiękowych wymaga przestrzegania kilku zasad. Przede wszystkim długość wersów zawierających daną wypowiedź musi być dostosowana do zdolności percepcyjnych odbiorców. Ta konieczność już na wstępie stwarza problemy przy transkrybowaniu dłuższych kwestii. Jeśli w dodatku aktor mówi bardzo szybko, to tworzone napisy siłą rzeczy muszą zostać skrócone, by zawrzeć sens wypowiedzi i jednocześnie pozwolić czytającemu na jego swobodne przyswojenie. W ten sposób odbiorca traci możliwość rozpoznawania wielu niuansów przekazu: żartów słownych, rytmu wypowiedzi, walorów poetyckich i tym podobnych. Widać to wyraźnie na przykładzie Pana Tadeusza Andrzeja Wajdy (1999), gdzie zrozumiałość przekazu musi górować nad pięknem trzynastozgłoskowca ${ }^{44}$. Istotne jest również wyróżnienie kolorystyczne poszczególnych wypowiedzi. Jeśli na ekranie pojawia się grupa postaci, które prowadzą dialog, osoba z niedosłuchem może mieć problem z przyporządkowaniem kolejnych fraz odpowiedniemu bohaterowi. Ponadto znaczące jest dostosowanie formy napisów do gatunków filmowych. Twórcy instrukcji tworzenia napisów dla niesłyszących podkreślaja, że: „Opracowujac napisy do filmu z suspensem (na przykład kryminalnego), należy zachować szczególną rozwagę przy nadawaniu kolorów - tak, by przedwcześnie nie zasugerować rozwiązania akcji, na przykład - wyróżniając kolorem pozornie mało znaczącego bohatera, który ostatecznie wywrze zasadniczy wpływ na fabułę" ${ }^{\prime 5}$.

Osobną kwestią jest fakt, że napisy do filmów polskojęzycznych są w zasadzie nieosiagalne poza emisjami telewizyjnymi. Widz oglądający projekcję w kinie skazany jest zatem na dyktaturę obrazu i wyłapywanie szczątkowych komunikatów z głosu i mimiki aktorów. Wydaje się, że mniejsze kłopoty sprawiają tłumaczenia filmów zagranicznych. Niestety, tak nie jest. Co prawda istnieje bogata baza napisów do kinowych produkcji (często bywają dołączane do wydań komercyjnych), jednak ich twórcy nierzadko nie podejmują trudu ich dostosowania. Albo transkrybowane kwestie są zbyt długie, albo po prostu nie przekłada się części wypowiedzi; tym samym dochodzi do zafałszowania przekazu. Pomijane są również - niezbędne w napisach dla niesłyszących - opisy odgłosów, dźwięków tła, określenia podkładu mu-

${ }^{44}$ Jak wyglądają przekształcenia tekstów, które wypowiadają aktorzy, można zobaczyć na Portalu filmowy dla niewidomych i niestyszacych „Adapter”, założonym przez Fundację na Rzecz Rozwoju Audiodeskrypcji KATARYNKA. Zob. Pan Tadeusz, reż. A. Wajda, < https:// adapter.pl/adapter-w-szkole/pan-tadeusz/> [dostęp: 27.06.2019].

${ }^{45}$ Napisy dla osób niestyszacych $i$ słabostyszacych - zasady tworzenia, <http://dzieciom. pl/wp-content/uploads/2012/09/Napisy-dla-nieslyszacych-zasady-tworzenia.pdf>, s. 5 [dostęp: 20.11.2018]. 
zycznego (np. „energiczna muzyka”, „głośne skrzypienie drzwi” itp.). Osobne utrudnienie stanowi coraz częściej stosowana praktyka dubbingowania obcojęzycznych produkcji. Istota problemu jest - podobnie jak w polskich filmach - niedodawanie napisów do projekcji, ale w tym przypadku odbiorca, zwykle nieznający języka, w którym wypowiadane są kwestie, pozbawiony zostaje jakiejkolwiek możliwości rozumienia warstwy słownej. Pozostaje mu jedynie śledzenie poruszających się obrazów.

Dodawanie napisów do filmów jest dużym udogodnieniem, jednak ma też swoje mankamenty. Jednym z najważniejszych jest - wyjątkowo prozaiczny - problem z jakością oferty kierowanej do odbiorców z wadami słuchu, na który zwraca uwage autorka bloga I'm not there:

Najbardziej irytuje mnie fakt, że chociaż wypełniaja [przedstawiciele firm odpowiedzialnych za dystrybucję filmów w telewizji i w formie nagrań - E. W-Cz.] nałożony na nich ustawowy obowiązek dodania napisów do części swoich programów, są to najczęściej słabe produkcje i średnie „hity”. Podobna godna ubolewania sytuacja jest w przypadku DVD polskich filmów (a także w wielu dodatkach dołączonych do filmów zagranicznych; tak strasznie żałuję, że nie mogę przeczytać komentarzy obsady do wielu filmów) ${ }^{46}$.

Ponadto niektórym osobom, zwłaszcza tym, które potrafią czytać z ruchu warg, bardzo przeszkadzają rozbieżności między tym, co bohater mówi, a tym, co zostało przetranskrybowane. Ze względu na konieczność dostosowania długości napisów do szybkości percypowania często zdarza się, że tekst nie pokrywa się z artykułowanymi wypowiedziami.

Powyższa analiza pozwala stwierdzić, że nie ma doskonałego sposobu dostosowywania filmów do możliwości percepcyjnych osób z wadami słuchu. Wybór udogodnienia jest kwestią indywidualna, ale warto mieć świadomość, że znacząco wpływa na sposób i jakość odbioru sztuki filmowej.

W tym miejscu warto przywołać artystyczny eksperyment ukraińskiego reżysera Myrosława Słaboszpyckiego, którym z pewnością jest Plemię, film w całości nakręcony wyłącznie w języku migowym, bez lektora i napisów. Abstrahując od tematu, jaki porusza kinowy obraz, warto skupić się na analizie narracji. Język migowy odgrywa tu podobną rolę jak w poezji miganej - jest nośnikiem ekspresji. Mimo że warstwa znaczeniowa nie jest czytelna dla wszystkich użytkowników, to zachowanie bohaterów, ich mimika, wzajemne interakcje decydują o uniwersalności przekazu.

Bohaterowie rozmawiaja między sobą w języku migowym i chociaż na ekranie nie ma tłumaczenia tych dialogów, akcja oraz emocje są przejrzyste i zrozumiałe. Słowa nie rozpraszają uwagi, nie wygładzają obrazu, nie tłumaczą zachowań, nie eufemizuja przestępstw. Brak werbalnego akompaniamentu obnaża pokazane na

${ }^{46}$ E. Pakalska, dz. cyt. 
ekranie emocje, a u widza wyostrza percepcję, ponieważ poniekąd zwalnia go z konieczności rozszyfrowywania mowy. Zmysły skupiają się na płaszczyźnie wizualnej, a to, co widzimy na ekranie, poraża swoją brutalnościa ${ }^{47}$.

Nowa forma stawia słyszącego odbiorcę po drugiej stronie percepcyjnej bariery - w tej samej sferze dyskomfortu, w której zwykle znajdują się głusi oglądający filmy dźwiękowe, jednak możliwość ekstremalnego doświadczania dominacji obrazu rekompensuje mu w pewnej mierze wyłączenie głosu. Taki seans zmusza do postawienia się w pozycji Innego. Może również podpowiadać ścieżkę prowadzącą do zmniejszenia problemów odbiorczych osób noszących aparaty słuchowe, które nie posługują się językiem migowym. Wystarczy, że filmy dźwiękowe zyskają czytelną warstwę wizualną. Oczywiście niemożliwe i niepożądane jest, by wszystkie produkcje dziesiątej Muzy tworzone były według klucza. Istotne jest, by twórcy byli świadomi istnienia odbiorców, którzy potrzebuja czytelnych przekazów obrazowych (co bynajmniej nie znaczy, że mają one być uproszczone i niewymagające percepcyjnie).

\section{Demokratyczna sztuka}

W ujęciu Berleanta „sztukę należy [...] pojmować jako kwintesencję, intensyfikację, skupienie się na bezpośredniości doświadczenia, na które nie zwracamy zazwyczaj tak dużej uwagi”"48, Czy istnieje bardziej bezpośredni sposób doświadczania, niż fizyczne odczuwanie dźwięku, tworzenie (i interpretowanie) utworów literackich za pomoca gestu, kontakt twarzą twarz z artystą lub widzem? Polisensoryczny odbiór dzieł muzycznych, filmowych, teatralnych, a nawet literackich u osób niesłyszących jest stanem naturalnym, pierwotnym, narzuconym przez specyfikę percepcji. Wyłączenie jednego zmysłu nie rekonstruuje dystansu ${ }^{49} \mathrm{w}$ odbiorze sztuki. Wręcz przeciwnie, sprawia, że relacja z dziełem staje się bardziej intymna, wręcz cielesna. Ciało jest tutaj nie tylko nośnikiem przekazu artystycznego (odbiera wibracje muzyczne, jest artykulatorem języka migowego, tworzywem poetycko-teatralnym), ale również odgrywa rolę katalizatora estetycznego doświadczenia dzięki wymuszonej konieczności bezpośredniego uczestniczenia w działaniach związanych ze sztuką (patrzenie na twarz, zachowanie bliskiej odległości, uważne obserwowanie zachowania, mimiki, emocji). Postrzeganie sztuki przez osoby $\mathrm{z}$ wadami słuchu w pewnych aspektach wydaje się nawet bardziej odkryw-

\footnotetext{
${ }^{47}$ J. Stępniewicz, dz. cyt.

${ }^{48}$ A. Berleant, dz. cyt., s. 124.

${ }^{49}$ Dystansu rozumianego jako porzucenie praktycznego kontekstu (jak w Kantowskiej estetyce tradycyjnej). Por. tamże, s. 62-64.
} 
cze i pełne niż to ma miejsce w przypadku słyszących odbiorców, dla których podobne sposoby percypowania są w dużej mierze niedostępne. Co zatem sprawia, że głusi wciąż sa grupą wykluczaną z kultury? Przede wszystkim fakt, że my - „zdrowi” - traktujemy ich jak „innych”, nierzadko gorszych, obcych, którzy żyją gdzieś obok. Nie pomaga również dobrowolne dystansowanie się Kultury Głuchych od słyszących. Część jej członków uważa się za mniejszość kulturowo-językową (mają ku temu podstawy), co w skrajnej postaci powoduje całkowitą izolację od obcego im świata. Warto zatem poszukać wspólnego mianownika dla obu - nie tak różnych przecież - światów. To właśnie sztuka oferuje niezliczoną ilość płaszczyzn porozumienia. W jej obszarze znajdzie się miejsce dla wszelkich różnic i inności, które nie tylko się nie wykluczaja, ale wzajemnie uzupełniają się i stymulują swój rozwój, ponieważ estetyczne doświadczanie sztuki jest potencjalnie nieograniczone.

\section{BIBLIOGRAFIA}

Bazak A., Poezja migana, 2014, <https://www.youtube.com/watch?v=XxxpXwwgHwU> [dostęp: 15.11.2018].

Bazak A., „Żegluga”. Warsztaty poezji miganej, 2018, <http://literatura.wroclaw.pl/wydarzenia/zegluga-warsztaty-poezji-miganej/> [dostęp: 18.11.2018].

Berleant A., Prze-myśleć estetykę. Niepokorne eseje o estetyce i sztuce, przeł. M. Korusiewicz, T. Markiewicz, red. K. Wilkoszewska, Kraków 2007.

Czym jest pętla indukcyjna?, <https://petlaindukcyjna.pl/czym-jest-petla-indukcyjna/> [dostęp: 26.11.2018].

Dobrze, że jesteś, 2014, <https://www.youtube.com/watch?v=XlLKOeHwK7s> [dostęp: 26.11.2018].

Dunaj M., GŁUCHY-ŚWIAT. Gtuchota w perspektywie antropologii zaangażowanej, Łódź 2015, <http://dspace.uni.lodz.pl/xmlui/bitstream/handle/11089/8015/dunaj-swiatgluchy-gluchota-w-perspektywie-antropologii-zaangazowanej.pdf?sequence=1\&isAllowed=y> [dostęp: 20.11.2018].

Godlewska-Byliniak E., Odzyskiwanie obecności. Niepetnosprawność w teatrze i performansie, Warszawa 2017.

Greniuk A., Cisza petna dźwięków, 2015, <http://www.niepelnosprawni.pl/ledge/x/251046> [dostęp: 26.11.2018].

<http://jezykowaoaza.pl/2015/03/jezyki-niezwykle-polski-jezyk-migowy/> [dostęp: 28.11.2018].

Kijewska A., Jak narysować dźwięk?, <https://www.vice.com/pl/article/mvz8dy/jak-narysowac-dzwiek> [dostęp. 16.11.2018].

Koczorowski O., Po wernisażu wystawy GAG w Katowicach, 2018, <http://www.gag.art. pl/2018/02/wernisazu-wystawy-gag-katowicach/> [dostęp: 16.11.2018].

Kowalski K., Architektura i rozwiazania techniczne, [w:] ABC Gość niepetnosprawny w muzeum, „Szkolenia Narodowego Instytutu Muzealnictwa i Ochrony Zbiorów” 
2013, 2, <https://www.nimoz.pl/files/publications/17/ABC_Gosc_niepelnosprawny_ lekki.pdf> [dostęp: 26.11.2018].

Legierska A., „Jeden gest”, reż. Wojciech Ziemilski, <https://culture.pl/pl/dzielo/jedengest-rez-wojciech-ziemilski> [dostęp: 10.11.2018].

Legierska A., Ziemilski: Jak zobaczyć głos, 2016, <https://culture.pl/pl/artykul/ziemilskijak-zobaczyc-glos-wywiad> [dostęp: 10.11.2018].

„Miganie pantoMimiczne - magia języka migowego” (Visual Vernacular), <http://pzg. warszawa.pl/miganie-pantomimiczne/> [dostęp:18.11.2018].

Napisy dla osób niestyszacych i stabostyszacych - zasady tworzenia, 2012, <http://dzieciom.pl/wp-content/uploads/2012/09/Napisy-dla-nieslyszacych-zasady-tworzenia. pdf> [dostęp: 20.11.2018].

Odziomek M., Dźwięk zaklęty w obrazach, czyli malarstwo zdobywczyni „,artNobla 2015”, 2016, <http://katowice.wyborcza.pl/katowice/1,35018,19604370,dzwiek-zaklety-w-obrazach-czyli-malarstwo-zdobywczyni-artnobla.html> [dostęp: 16.11.2018].

Pakalska E., Niedoskonaty odbiornik < https://pakalska.blogspot.com/2015/03/niedoskonay-odbiornik.html > [dostęp: 27.06.2019].

Poezja migana, <http://pzg.warszawa.pl/poezja-migana/> [dostęp: 25.11.2018].

Sacks O., Zobaczyć głos. Podróż do świata ciszy, przeł. A. Małaczyński, Poznań 1998.

Stępniewicz J., Bez znieczulenia. Recenzja „Plemienia” Myrostawa Staboszpyckiego, 2015, $<$ https://kulturaliberalna.pl/2015/06/16/bez-znieczulenia-recenzja-plemienia-myroslawa-slaboszpyckiego/> [dostęp: 29.10.2018].

Szwoch G., Analiza dźwięków muzycznych, 2018, <https://sound.eti.pg.gda.pl/student/ akmuz/02-Analiza.pdf> [dostęp: 16.11.2018].

Żórawska A., Gość z niepetnosprawnościq stuchu w muzeum, [w:] ABC Gość niepetnosprawny $w$ muzeum. Szkolenia Narodowego Instytutu Muzealnictwa $i$ Ochrony Zbiorów, 2013, nr 2, <https://www.nimoz.pl/files/publications/17/ABC_Gosc_niepelnosprawny_lekki.pdf> [dostęp: 10.11.2018]. 
